\title{
Prospects for the development of social entrepreneurship in Ukraine: the impact of the COVID-19 pandemic
}

\author{
Zinaida Smutchak $^{1 *}$, Mariia Buhaieva $^{2}$, Liliya Filipishyna ${ }^{3}$, Alla Hrusheva ${ }^{4}$, and Oksana \\ $\mathrm{Ursol}^{5}$ \\ ${ }^{1}$ Flight Academy of National Aviation University, Department of Management and Economics, 1 \\ Dobrovolsky Str., 25005, Kropyvnytskyi, Ukraine \\ ${ }^{2}$ Central Ukrainian National Technical University, Department of Economics and Entrepreneurship, 8 \\ University Ave., 25006, Kropyvnytskyi, Ukraine \\ ${ }^{3}$ Pervomaisk Branch of the Admiral Makarov National University of Shipbuilding, Department of \\ Economics and Organization of Production, 107 Odeska St., 55200 Pervomaisk, Ukraine \\ ${ }^{4}$ University of the State Fiscal Service, Department of Management, 31 Universytetska str., 08200 \\ Irpin, Kiev region, Ukraine \\ ${ }^{5}$ Flight Academy of National Aviation University, Department of Professional Education and Social- \\ Humanitarian Sciences, 1 Dobrovolsky Str., 25005, Kropyvnytskyi, Ukraine
}

\begin{abstract}
The article reveals the essence of social entrepreneurship, describes the main stages of its development in Ukraine. The activity of social enterprises is beneficial for the macroeconomic development of each country, as this activity makes it possible to reduce part of government spending on solving the problems of socially disadvantaged people, their employment and social adaptation. Since the beginning of the COVID-19 pandemic, social entrepreneurship has found itself in conditions of complete legal uncertainty. The crisis economic situation has created many challenges in the context of the sustainability of social enterprises, forced to reconsider existing business models, and in some cases to cease operations. The process of popularization of social entrepreneurship can be accelerated by conducting an active social and economic policy, considering its formation as an important independent direction of the policy of social and economic reforms. It is the increase in the activity of citizens through the creation of social enterprises, their cooperation with the authorities that will allow Ukraine to begin solving such an extremely important problem as building a welfare state and civil society.
\end{abstract}

\section{Introduction}

Social entrepreneurship is an important and effective tool for solving social problems, both for civil society and for small and medium-sized businesses in our country. The growing urgency of this theme for Ukraine is due, firstly, to the reaction of society to social,

\footnotetext{
* Corresponding author: zinulechka@ukr.net
} 
economic and political challenges associated with Russian military aggression against Ukraine, and secondly - to the process of reforming the country as a whole.

In order to support the sustainable development of social entrepreneurship, which will contribute to the democratization and stabilization of Ukraine, consolidated support from international donors and systematic support for the development of this area by the Ukrainian state is needed. It is worth noting that social entrepreneurship is a relatively young business tool in Ukraine, which through innovative concepts responds to social challenges, creates additional social value and, at the same time, generates income for its further development. One of the main rewards for a social entrepreneur is the recognition of his mission and work results.

Thus, the functioning and development of social entrepreneurship, as one of the tools for solving social problems, in this aspect is relevant. The development of social entrepreneurship in Ukraine is made possible by strengthening the role of economically active participants in the national market in supporting socially vulnerable categories of citizens and addressing socially significant issues. However, the spread of social enterprises in Ukraine is blocked by the lack of legislation that would regulate the activities of social enterprises and the uncertainty of key concepts and criteria for identifying such enterprises.

\section{Methods}

The purpose of the article is to clarify the essence of the concept of social entrepreneurship, study the prospects for its development in Ukraine, given the impact of the COVID-19 pandemic. To solve this goal, theoretical methods of scientific research were used: analytical - to collect, summarize and process scientific information on the state of development of social entrepreneurship in Ukraine; economic-mathematical, statistical - in order to comparatively assess the trends of social entrepreneurship in Ukraine; graphic - for visual interpretation of theoretical positions, the received results of research; generalization - to formulate conclusions based on research results.

\section{Results and discussion}

Social entrepreneurship emerged as a response to chronic social problems: unemployment, poverty, community disunity, and so on. Social enterprises are designed to meet the needs of community members that the public sector cannot meet and the private sector ignores. This is a niche for the activities of social enterprises.

The local communities benefit mostly from the development of social entrepreneurship, because social entrepreneurship helps to: provide public services in a new way and meet the needs of the community; create working places; to enrich the professional experience of people working in social enterprises for further employment in modern market conditions; to develop communities, involving socially vulnerable and marginalized groups in public life, providing their members with jobs; to expand the activity of citizens who can solve their own problems and take responsibility for their lives; increase attention to socially disadvantaged groups, not so much by providing them with charitable assistance, but by providing them with useful socially significant work; to revive rural and urban areas and improve their social infrastructure, etc. [1, 2, 3, 4].

As a phenomenon, social entrepreneurship began to develop in Europe and the United States in the mid-1980s. According to an analytical study [5], the term "social enterprise" was first used in Ukraine only in the late 1990s. In 1999, the global partnership organization Counterpart International, Inc. introduced its use for NGOs through a training and grant program that lasted until 2002. 
Ukrainian researchers $[6,7]$ note that the term "social entrepreneurship" came into full circulation in Ukraine only in 2004, when the implementation of the project "Public Action Network in Ukraine", implemented by the Institute for Sustainable Communities funded by the United States Agency for International Development. in 2004-2008. However, V. Nazaruk [7] in his research notes that in the early twentieth century, Metropolitan Andrei Sheptytsky actively implemented the principles of social entrepreneurship and cooperation in doing business in Western Ukraine.

A. Kornetsky and B. Androschuk [6] identify three main stages in the development of social entrepreneurship in Ukraine.

The first is called the period 1991-2010, when international donors, in particular the United States Agency for International Development, began to finance the development of social entrepreneurship in Ukraine. In 1991, the Law of Ukraine "On the Fundamentals of Social Protection of Persons with Disabilities in Ukraine" was adopted. It is still in force and provides benefits for doing business for people with disabilities, in particular, determines the financing of their business initiatives from a special state fund.

The second stage defines the period 2010-2016, which was characterized by the merger of partner organizations into consortia to launch educational and financial programs for social entrepreneurship. In 2010, the Consortium for the Promotion of Social Entrepreneurship in Ukraine was established, supported by a series of trainings for trainers, three resource centers were opened (in Kyiv, Donetsk and Lviv) and the first lending program for social enterprises was launched. During this period, the publication of educational materials on social entrepreneurship began.

In 2012, the All-Ukrainian Resource Center for Social Entrepreneurship Development "Social Initiatives" was established. In 2013, the first information web portal for social entrepreneurs was created - socialbusiness.in.ua. It still works today. V. Nazaruk [7] emphasizes that 2013 became a landmark for the development of social entrepreneurship in Ukraine, because this year the first "Catalog of Social Enterprises of Ukraine 2013" was compiled, the "First All-Ukrainian Forum of Social Entrepreneurs" was held, and the first attempt to legislate social entrepreneurship took place.

It is believed that the third stage of development of social entrepreneurship began in 2016 and continues to this day. Significant assistance in the development of social entrepreneurship in Ukraine during this period is provided by the European Union (EU) and some EU member states. For example, thanks to the financial support of the Federal Ministry for Economic Cooperation and Development of Germany, the NGO ChildFund Deutschland e.V. in partnership with the Eastern Europe Foundation in 2016 launched the implementation of the program "Promoting the development of intersectoral partnership to protect the interests of children: the involvement of IDPs in active processes". Its goal was to develop social entrepreneurship in the eastern and southern regions of Ukraine in order to improve the social and economic situation of vulnerable groups by combining the efforts of business, government and the local community.

Social entrepreneurs are often called innovators because they try to solve "old" social problems with "new" entrepreneurial approaches. This is primarily due to the fact that traditional business has occupied the most interesting, in terms of profitability, niches, and the peculiarity of social groups that find themselves in difficult life circumstances. In fact, it is sometimes necessary to "combine the incompatible" to obtain commercial and social / environmental effects. For example, Ashoka (www.ashoka.org) seeks out and supports social entrepreneurs around the world who offer non-standard solutions to social problems.

Most researchers link social entrepreneurship with innovations and even call social entrepreneurship innovation in the social sphere, at least in countries where social entrepreneurship is just beginning to develop. Prerequisites for innovation in the social sphere of Ukraine are: 
1. Availability of resources, that are not interesting to traditional business;

2. Increasing the number of public organizations and their "global mobilization";

3. Availability of sources, where you can learn innovation.

At the present stage, the activities of social enterprises extend to various components of social life, however, most attention is focused on the employment of vulnerable groups, because it allows such people to realize themselves, supporting the country's economy. This trend is the most objective and justified, because with the intensive development of social enterprises, such an approach will not only reduce unemployment in the country, but also reduce the total amount of unemployment benefits and, consequently, - will increase budget revenues. Therefore, the state will allow citizens to provide for themselves and take a step towards stable economic development and social security [3].

Note that the activities of social enterprises are beneficial for the macroeconomic development of each country, as these activities make it possible to reduce part of government spending on solving the problems of socially disadvantaged people, their employment and social adaptation. Social entrepreneurship has the following components: a social problem that has existed in society for a long time due to the limited access of a certain target group to financial and political resources to solve it; development and implementation of a mechanism for innovative solution to a problem that violates a stable but unfair balance; creating a new, sustainable balance that frees up resources for the mentioned target group and provides a better future not only for these people, but also for society as a whole $[8,9]$.

The COVID-19 pandemic has become a significant test for each country in terms of the ability of its state apparatus to cope with the challenges it poses to both the health care system and the economic sector. Ukraine, like other EU countries, in order to prevent the spread of coronavirus infection, decided to impose strict quarantine in early spring 2020.

The introduced measures included a ban on visiting educational institutions, as well as a ban on all mass events with the participation of more than 200 people, except for the measures necessary to ensure the work of public authorities and local governments, in particular, prohibited: holding all mass (cultural, entertainment, sports, social, religious, advertising and other) events with the participation of more than 10 people, except for the measures necessary to ensure the work of public authorities and local governments; work of business entities, which provides for the reception of visitors, in particular catering establishments (restaurants, cafes), shopping and entertainment centers, other entertainment establishments, fitness centers, cultural institutions, trade and consumer services, except for retail trade food, fuel, hygiene products, medicines and medical devices, means of communication, carrying out banking and insurance activities, as well as trade and catering activities with the use of targeted delivery of orders, provided that the relevant personnel are provided with personal protective equipment; regular and irregular transportation of passengers by road in suburban, long-distance intra-regional and inter-regional communication (except for transportation by cars), etc. [10,11].

Under such conditions, Ukrainian social enterprises, whose activities mostly fall under the above-mentioned first and second categories of prohibitions, found themselves in a critical situation.

Such uncertainty about the actual duration of the bans had a negative impact on the resilience of all social enterprises, even those with a fairly efficient and flexible business model, as a three-week quarantine was first announced and later extended in several stages. It should be noted that the need to revise the business model has become one of the main tasks that most social entrepreneurs needed to solve in the first months after the introduction of quarantine restrictions. Even relatively large companies that had more than 2 years of experience were forced to review and optimize their production processes. 
It is worth noting that for the most part, social enterprises in Ukraine operate as micro or small businesses with a staff of up to 5 people (Fig. 1). Enterprises of this scale can more quickly transform and optimize their production processes, as well as adapt to new changes. Therefore, in the conditions of effective management, most of them managed to reorganize their activities by the beginning of summer 2020 .

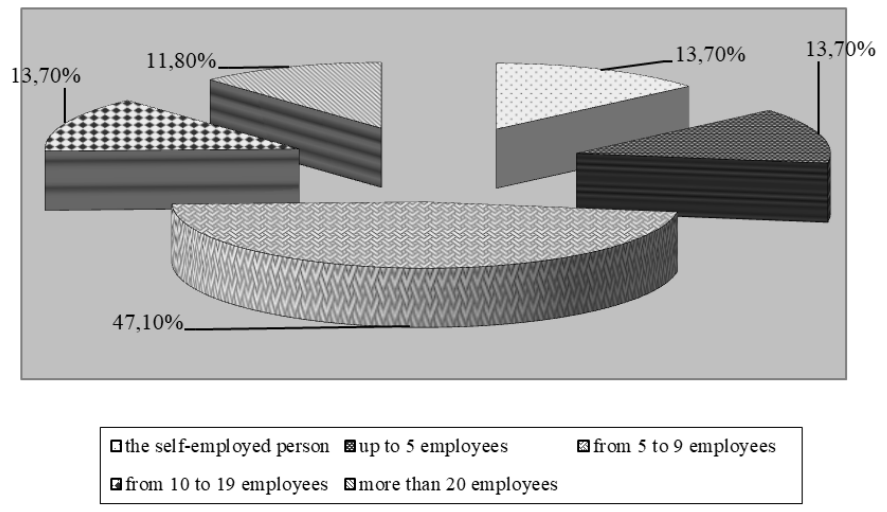

Fig. 1. Distribution of social enterprises by number of employees.

Due to the fact that quarantine restrictions in Ukraine were not lifted, but constantly underwent certain transformations, all social enterprises were forced to adapt their work schedule to the new conditions, some of them transferred employees to part-time work and introduced remote mode. The survey [9] shows that mostly social enterprise teams remained stable, despite the risk of potential layoffs.

This may be the result of uniting the employees of these enterprises, first of all, with common values and beliefs, and not for commercial purposes. However, it should be noted that the fact of declining purchasing power of customers in the market, as well as changes in their consumer behavior and priorities in deciding to purchase certain goods showed during the survey $62.8 \%$ of respondents (Fig. 2)

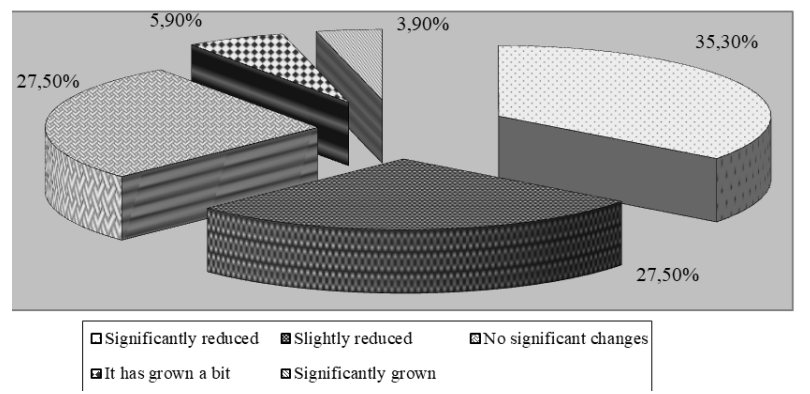

Fig. 2. Distribution of social enterprises by number of clients [9].

Note that the most significant effects of the crisis caused by the COVID-19 pandemic on the activities of social enterprises should be called (Fig. 3):

Given the specifics of social enterprises, the loss of previous suppliers of raw materials or sales channels affects their activities much more than the activities of classical (commercial) enterprises. In most cases, the work of social enterprises with contractors is based on special individual contractual terms, which take into account the special nature of their activities and provide certain benefits (for example, lower purchase price, lower cost of logistics services, additional services, etc.). 


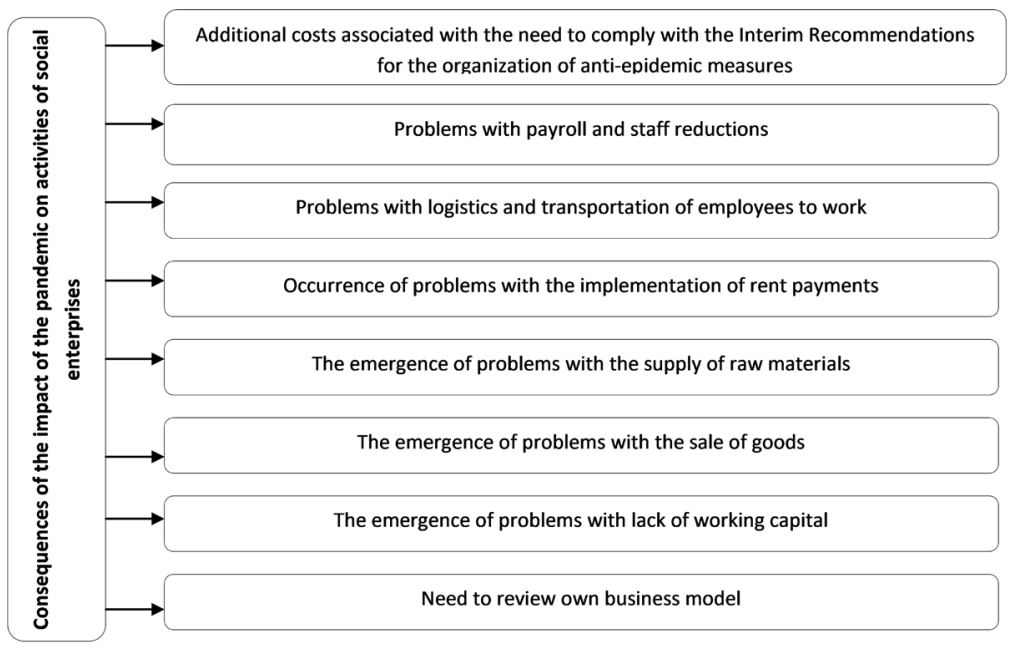

Fig. 3. Consequences of the impact of the crisis caused by COVID-19 on the activities of social enterprises.

It should be noted, that the introduction of bans on business activities by the state did not provide for compensation for losses incurred by entrepreneurs. And support for social entrepreneurship at the state level in Ukraine is provided exclusively within the framework of supporting small and medium-sized businesses [9, 12-14].

Despite the fact that the history of social entrepreneurship in Ukraine had only a few decades, it has already proven itself as an effective tool for solving various social problems, as evidenced by the growing interest in this phenomenon from both practical and theoretical points of view in Ukraine during last years.

However, despite numerous success stories, the activities of social entrepreneurs in our country still remain unregulated. The latter presupposes both the lack of a legislative definition of the term "social enterprise" and its derivatives, the criteria for granting this status to a certain enterprise, and the state policy on the development and support of social entrepreneurship. As a result, existing social entrepreneurs and people who wish to acquire this status become dependent on international donor support and are at risk of abuse and manipulation. As a result, it creates instability and insecurity in this sector of the economy [15-17].

The creation and development of social entrepreneurship is often associated with the perceived need to solve social problems and respond to the challenges facing the community or society as a whole and which for various reasons can not yet be solved by the state. Thus, most of the created social enterprises arose in response to the need to create jobs for internally displaced persons and ATO participants, provide social services to categories of people who remain out of the state's attention, develop new areas that will promote interaction between public and public sectors (IT solutions).

The lack of strong teams in social enterprises also affects the activities of social entrepreneurship. Note that in the context of globalization there is a rapid intensification of international mobility of the population of Ukraine, so it is important to take into account the fact that Ukrainian migrants are desirable workers in many countries, where despite economic difficulties trying to keep them [13, 14, 18-20].

We emphasize that the provision of social services in Ukraine is needed by different categories of citizens. Their social needs determine the need for the existence of social enterprises; determine their social mission, as well as the potential market [21-24]. It should be noted that consumers of goods, services of social entrepreneurship are other categories 
of citizens, as such enterprises can produce not only narrowly oriented products or provide specialized services, social enterprises can operate in many areas (for example, agroindustrial cooperatives to reduce unemployment in rural areas, etc.)

\section{Conclusions}

The development of social entrepreneurship in Ukraine is a long process, the scale and pace of which cannot be predicted, which is explained by the decentralized nature of these processes. Significant negative impact on the spread of social entrepreneurship in Ukraine is caused by the lack of regulatory framework that would regulate the activities of social enterprises, as well as a small amount of information in the media about the activities of many enthusiastic entrepreneurs.

According to the law, in most European countries, public authorities (especially at the local level) can grant privileges to social enterprises to support their social mission.

The process of popularization of social entrepreneurship can be accelerated by conducting an active social and economic policy, considering the formation of yoga as an important independent direction of the policy of social and economic reforms.

It is the increase in the activity of citizens through the creation of social enterprises, their cooperation with the authorities will allow Ukraine to begin solving such an extremely important problem as building a welfare state and civil society, which is the prospect of further research.

\section{References}

1. C. Seelos, J. Mair, Social Entrepreneurship the contribution of individual entrepreneurs to sustainable development, 19 (2004)

2. N. Ignatovych, V. Gura, Foreign experience of social entrepreneurship development. Bul. Of the Kuiv Nat. Un.n.a. T. Shev. 165, 22-25 (2014)

3. O. Kireeva. Social entrepreneurship as an instrument of state social policy. Pub. ad th. and pr. el. col. sc. works. 2 (6) (2011)

4. Z. Smutchak, M. Romaniuk, Migratory threats to national security of Ukraine: current challenges and ways of regulation. Balt. Jour. of Ec. Stud., 2(3), 107-112 (2016)

5. L. Shergina, Social entrepreneurship in the context of sustainable development. Bul. of Khmel. Nat. Un. 3(2), 160 - 165 (2018)

6. B. Androschuk, A. Kornetsky, Social Entrepreneurship: An Effective Tool for Overcoming Social Challenges in Ukraine? (2018)

7. A. Svinchuk, A. Kornetsky, M. Goncharova. Social entrepreneurship: from idea to social change (K: LLC "VENE", 2017)

8. O. Sotula, Social entrepreneurship as an innovative model of economic development. Ef. ec, 4 (2013)

9. L. Antonyuk, Social entrepreneurship in Ukraine during COVID-19 through the prism of gender equality (2020)

10. Resolution of the Cabinet of Ministers of Ukraine "On prevention of the spread on the territory of Ukraine of acute respiratory disease COVID-19 caused by coronavirus SARS-CoV-2" 11211 from 11.03 (2020)

11. Resolution of the Cabinet of Ministers of Ukraine "Amendments to the Resolution of the Cabinet of Ministers of Ukraine of March 11, 2020 № 211" № 215 of March 16 (2020)

12. J. Emerson, The blended value map: Tracking the Intersects and Opportunities of Economic, Social and Environmental Value Creation 182 (2003) 
13. O. Hutsaliuk, V. Koval, O. Tsimoshynska, M. Koval, and H. Skyba, Risk Management of Forming Enterprises Integration Corporate Strategy TEM J. 9(4) (2020)

14. O. Hutsaliuk, Z. Smutchak, O. Sytnyk, N. Krasnozhon, O. Puhachenko, A. Zarubina. Mass labour migration in the vector of international tourism as a determinant sign of modern globalization, Turismo: Estudos \& Práticas, 3, (2020)

15. O. Yankovyi, Yu. Goncharov, V. Koval, T. Lositska, Optimization of the capital-labor ratio on the basis of production functions in the economic model of production, Naukovyi Visnyk Natsionalnoho Hirnychoho Universytetu 4 (2019)

16. Y. Kvach, N. Piatka, V. Koval, Management of sustainable entrepreneurship adaptation to tax changes in environmental investment, Balt. J. Econ. Stud. 6, 96 (2020)

17. H. Bukanov, A. Kolesnyk, O. Tashkinova, V. Kotlubai, V. Koval Social marketing in public administration of social service institutions. Revista Genero \& Direito 8(6), 457468 (2019).

18. V. Koval, Y. Mykhno, L. Antonova, D. Plekhanov, V. Bondar, J. Analysis of environmental factors' effect on the development of tourism, Geol. Geogr. Geoecology 28, 445 (2019)

19. O. Popova, V. Koval, L. Antonova, A. Orel, Corporate social responsibility of agricultural enterprises according to their economic status, Manag. Theory Stud. Rural Bus. Infrastruct. Dev. 41, 277 (2019)

20. O.V. Prokopenko, Consumer choice types in marketing of ecological innovations. Actual Problems of Economics 16(2), 109-116 (2011)

21. O. L. Popova, V. V. Koval, I. S. Mikhno, I. Tarasov, N. Asaulenko, L. Filipishyna, J. Geol. Geogr. Geoecology 29, 377 (2020)

22. M. Chorna, A. Krutova, L. Filipishyna, L. Bezghinova, and O. Drobysheva, Journal of Entrepreneurship Education 22 (1S), (2019)

23. O. Yankovyi, O. Hutsaliuk, V. Tomareva-Patlakhova, N. Shmatko, O. Kabanova, and Y. Rud, in 2020 International Conference on Decision Aid Sciences and Application (DASA) (IEEE, 2020).

24. O. Hutsaliuk, I. Bondar, N. Sereda, O. Babych, and I. Shchoholieva, E3S Web Conf. 255, 01026 (2021) 